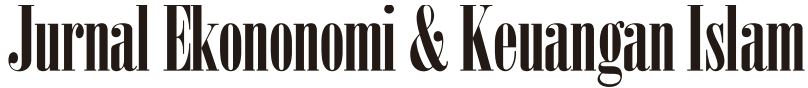

Available at http://journal.uii.ac.id/index.php/jeki

\section{A comparison of non-financial performance and earnings quality between QIIB and BIB}

\author{
Yunice Karina Tumewang \\ Faculty of Economics, Universitas Islam Indonesia, Yogyakarta, Indonesia \\ E-mail: yunice.karina@uii.ac.id
}

\section{Keywords:}

Islamic Banking, Financial Performance, Non-Financial Performance.

DOI:

10.20885/JEKI.vol5.iss1.art4

\begin{abstract}
This study aims to evaluate and compare the non-financial performance and earnings quality of Islamic Banks in two different counties complying two different accounting standards, namely Qatar International Islamic Bank (QIIB) and Bahrain Islamic Bank (BIB). This study used quantitative method with secondary data from the annual report of QIIB and BIB. This study sheds light on the financial and non-financial performance of QIIB and BIB as well as the difference between them. It provides a picture for the Islamic Finance industry regarding the performance of these two banks and what the implication of adopting different accounting standard on this case. Additionally, it helps to raise the awareness of society about the existence of Islamic banks and how well they have performed. As far as we are concerned, there is only small number of research on finding the significance of accounting standard adoption toward performance of Islamic banks, although the urgency is increasingly growing for a better convergence and significant development of Islamic banks. This work is an attempt to fill in this gap.
\end{abstract}

\begin{abstract}
Abstrak
Penelitian ini bertujuan untuk mengevaluasi dan membandingkan kinerja non-keuangan dan kualitas pendapatan Bank Islam di dua negara berbeda yang memenuhi dua standar akuntansi yang berbeda, yaitu Qatar International Islamic Bank (QIIB) dan Bahrain Islamic Bank (BIB). Penelitian ini menggunakan metode kuantitatif dengan data sekunder dari laporan tahunan QIIB dan BIB. Studi ini menyoroti kinerja keuangan dan non-keuangan QIIB dan BIB serta perbedaan di antara mereka. Ini memberikan gambaran bagi industri Keuangan Islam mengenai kinerja kedua bank ini dan apa implikasi dari penerapan standar akuntansi yang berbeda pada kasus ini. Selain itu, ini membantu untuk meningkatkan kesadaran masyarakat tentang keberadaan bank syariah dan seberapa baik mereka telah melakukan. Sejauh yang kami ketahui, hanya ada sedikit penelitian tentang menemukan pentingnya adopsi standar akuntansi terhadap kinerja bank syariah, meskipun urgensi semakin tumbuh untuk konvergensi yang lebih baik dan pengembangan signifikan bank syariah. Karya ini merupakan upaya untuk mengisi celah ini.
\end{abstract}

\section{Introduction}

The growth of Islamic finance industry worldwide was so much better as it brought about business opportunity for various industries, particularly in the terms of sharia- compliant banking and capital market sector. In 2015, global Islamic financial industry consisted of sharia-compliant banking accounting for US\$ 1496.5 million or $80 \%$ of total global Islamic financial asset, and sukuk (sharia-compliant bond) for US\$290.6 million or $15.45 \%$ of total global Islamic financial asset. Over the years, Islamic banking contributes the largest chunk of the global Islamic finance industry. In 2023, the world sharia-compliant financial industry will predictably have assets up to US\$ 8.6 trillion. Even Indonesia is predicted to lead the world sharia-compliant financial industry in 2023 with total asset of US\$ 1.597 trillion.

However, as witnessed today, the development of Islamic banking as the core sector of Islamic finance is still far from satisfying the expectation. According to Financial Service Authority (OJK, 2017), the total asset of Islamic banking is only around IDR 400 Trillion or equal to 5.18\% of national banking asset. In line with that, the market share of Islamic banking is merely $5.78 \%$ of the national banking. Whereas on the total fund collected from society, Islamic banking is only able to acquire IDR 341 Trillion compared to the total society fund in national banking which is not less than IDR 5,289 Trillion. On the side of distributing fund to society, the number is quite the same, IDR 291.18 Trillion from Islamic banking compared to IDR 4,782 Trillion from total national banking.

The under-performance of Islamic banking is considered due to a limited variety of product diversification offered, less differentiation of Islamic banking toward its counterpart, and low literacy level of Islamic banking among society. According to Head of Commissioner Board of Indonesia Deposit Insurance Corporation (LPS), Halim Alamsyah, one of the factors hindering the acceleration of Islamic banking is that they 
merely focus on the role as an ordinary intermediary function, rather than maximizing their potential role as an investment or social agent. Hence, it made no difference with the conventional one. They, supposedly, can do better if they are more willing to manage the social funds for investment on real-sector activities which is highly Sharia-compliant and socially-impactful.

However, in the practitioner of Islamic banks' perspective, Islamic banks are more than willing to create a fully Sharia-compliant system. However, no matter how great the system and intention are, it is impossible without gaining trust, support, and cooperation from the society. Furthermore, Indonesia as the largest Muslim population country ideally should be able to cater to the need of the citizens to practice Islam as a whole (kaffah). By doing this, this is not impossible for Indonesia to be the hub of Islamic finance in 2030. With two-way collaboration between the government in voicing Islamic finance as the new alternative of economics and the society as the main players, we could boost the performance of Islamic banks globally, particularly in Indonesia.

"For every organization including Islamic Bank, performance measurement systems are necessary tools used in the strategic process to evaluate the accomplishment of its vision and mission over a period of time. With the increased level of globalization, strong competition, and technology development, many organizations have started to use a blend of financial and non-financial measures for their performance (Kaplan \& Norton, 1996; Raphael \& Man, 2013). Kaplan and Norton $(1992,1996)$ pointed out that the financial measures of performance are not enough to capture a full picture of a company's performance. Stakeholders who rely only on financial performance measures usually end up with an incomplete view of what happened inside the company and then failed to predict what will happen in the future. On the other hand, the use of balanced performance measures that mix financial and nonfinancial measures can serve as a focal point of the organization's efforts defining and communicating its priorities to different groups of stakeholders (e.g., managers, employees, investors, customers, and the public)."

Taking a closer at Islamic banks in which Sharia law is supposed to be incorporated in their practices, people will expect them to provide services beyond the conventional one. (Abu-Tapanjeh, 2009). They are anticipated to not just focus on being profitable, but also to conduct a more ethical practice and social initiative within their activities (Maali, et al., 2006). For maintaining the accountability, Islamic banks are mandatory to provide disclosure in annual report about the operational activity particularly which will affect the stakeholders. There are two widely applied standards for the disclosure of Islamic banks which are AAOIFI standard and IFRS. They differ in the criteria on which information should be disclosed. Therefore, Islamic banks might have different appearance on disclosure due to the adoption of different standard (Belal, et al., 2014).

Previous studies prove that non-financial measurement could help boosting the performance of organizations in most cases. "The association is often weak, however; there is considerable variation in the experience of individual organizations. Attempts to predict which types of organizations will benefit more from nonfinancial measures than others had mixed results (Hoque \& James, 2000; Randall, 2003)".

This essay will critically analyse and compare the non-financial performance of two Islamic Banks which comply two different accounting standards namely Bahrain Islamic Bank (AAOIFI standard) and Qatar International Islamic Bank (IFRS) from 2013 to 2015.

\section{Research Method}

By its explanation level, this research belongs to a comparative-associative (causal) study. A comparative study is a research form or method conducted to compare a variable (Supriyanto, 2009: 117); this current study compares efficiency value of sharia-compliant public banks in Qatar and Bahrain. Associative (causal) study is the one conducted to find out the effect or the relationship between one variable and another (Supriyanto, 2009:118). Hence, it can be said that this research, by its explanation level, is a combined comparative and associative causal study (Supriyanto, 2009:118).

This study employed a quantitative data analysis by processing data of non-financial performance of these two banks. Quantitative data is data in numerical form. In line with its form, quantitative data can be processed or analysed using statistic calculation technique (Siregar, 2013:23). Data source employed in this research was secondary data, the one obtained in the finished form, collected and processed by other parties, usually in publication and documented form (Suryani, 2015:171). Data obtained derived Islamic bank's non-financial performance in 2013-2015 published by the official website of each Islamic bank being the sample of this research.

The sampling technique method employed in this research was non-probability sampling, the one not giving equal opportunity to every element or member of population to be selected as the sample. From various nonprobability sampling techniques, the author implemented the purposive sampling technique, the technique of selecting the sample based on certain criteria corresponding to the research objective (Sugiyono, 2007:66-67). The criteria of sampling in this research is the best Sharia-compliant public bank operated in two different countries adopting two different accounting standards which present financial statements during observation period of 20132015 available in the official website of corresponding Sharia-compliant public bank. 


\section{Result and Discussion}

Qatar International Islamic Bank and Bahrain Islamic Bank are chosen because they could represent two different countries (with different characteristics as appeared in the score of cultural dimension formulated by Hofstede). "According to Worldwide Governance Indicator as shown in Table, Qatar has better score than Bahrain in all six indicators. Moreover, based on a study conducted by Mohammed and Ibrahim (1996) which employed the cultural dimension developed by Hofstede, Qatar outperformed Bahrain in the indicators of power distance, individualism, and uncertainty avoidance." According to several previous studies including Jain (2018), this cultural dimension is linked to transparency as a significant topic in accounting nowadays. It reveals that people with low power distance express greater preference for transparency than those with high power distance. As pointed out by Tucker (2015), this lack of transparency could lead to low earnings quality.

Table 1. Governance Indicator for Bahrain and Qatar

\begin{tabular}{|c|c|c|c|c|c|c|c|c|c|c|c|c|c|c|c|c|c|c|}
\hline & \multicolumn{3}{|c|}{ Voice \& Acc } & \multicolumn{3}{|c|}{ Political Stability } & \multicolumn{3}{|c|}{ Gov Effectiveness } & \multicolumn{3}{|c|}{ Regulatory Quality } & \multicolumn{3}{|c|}{ Rule of Law } & \multicolumn{3}{|c|}{ Control of Corrupt } \\
\hline & 2013 & 2014 & 015 & 2013 & 2014 & 2015 & 2013 & 2014 & 2015 & 2013 & 2014 & 2015 & 2013 & 2014 & 2015 & 2013 & 2014 & 2015 \\
\hline & & & & & & & & & & & & & & 0. & & & 0.30 & \\
\hline Qatar & -0.86 & -0.99 & 1.01 & 1.19 & 0.98 & 0.98 & 1.08 & 0.99 & 1.00 & 0.75 & 0.57 & 0.69 & 1.05 & 0.99 & 0.88 & 1.25 & 1.09 & 0.98 \\
\hline
\end{tabular}

Source: Worldwide Governance Indicator

Table 2. Hofstede Cultural Dimension for Bahrain and Qatar

\begin{tabular}{l|l|l|l|l|l|l|}
\hline & Power Distance & Individualism & Masculinity & $\begin{array}{l}\text { Uncertainty } \\
\text { Avoidance }\end{array}$ & $\begin{array}{l}\text { Long-term } \\
\text { Orientation }\end{array}$ & Indulgence \\
\hline Bahrain & 46 & 38 & 53 & 77 & - & - \\
\hline Qatar & 59 & 40 & 43 & 89 & - & - \\
\hline
\end{tabular}

Source: At-Twaijri and Al-Muhaiza (1996)

Furthermore, in their annual reports, both Islamic Banks declare that they fully comply with AAOIFI (Accounting and Auditing Organization for Islamic Financial Institution) standards. As a matter of fact, Bahrain which is located in the headquarters of AAOIFI is assumed to be more willing than Qatar to adopt AAOIFI standards as appeared in its annual report. In term of the reliability of their annual report, both Banks never missed the unqualified opinion from their external auditors which are among "The Big Four".

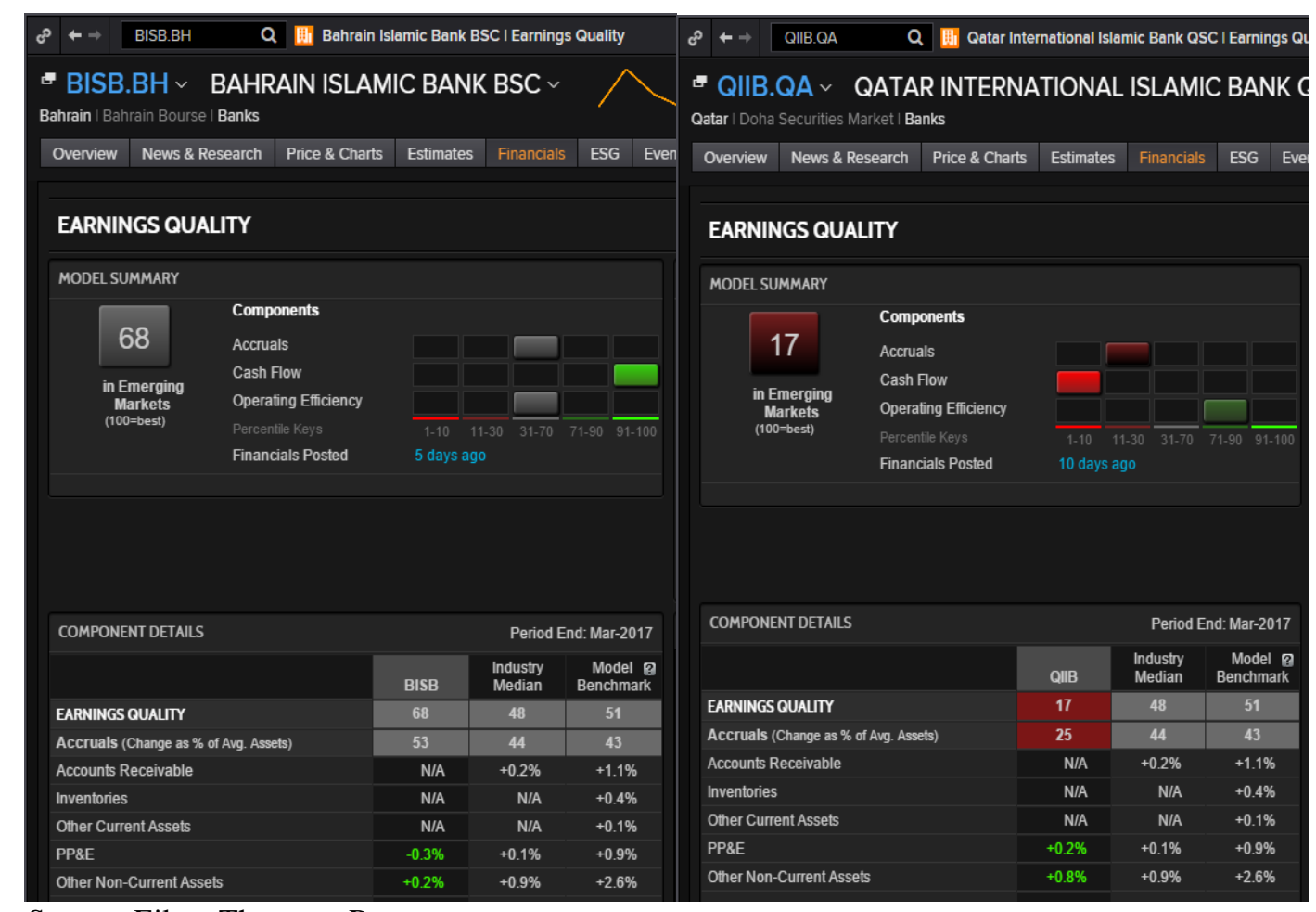

Source: Eikon Thomson Reuters

Figure 1. Earnings Quality of BIB and QIIB 
From those reliable annual reports, we will take a look at the non-financial information of QIIB and BIB which are Corporate Governance Disclosure and, Environmental Disclosure. After having the non-financial information, we have a comparison between the two and then figure out the relationship toward earnings quality score obtained from Eikon Thomson Reuters. As what depicts in Figure 1, BIB obtains high earnings quality score of 68 which is higher than the industry median and model benchmark. On the other hand, QIIB obtains low score of 17 which lies far below the industry median and model benchmark.

According to Dechow et al. (2010), "higher quality earnings provide more information about the features of a firm's financial performance that are relevant to a specific decision made by a specific decision maker. The quality of earnings is usually defined in accounting studies from two different perspectives, the decision-usefulness perspectives and the economic-based perspectives. From a decision-usefulness perspective, earnings quality is regarded as being high if the earnings numbers are useful for decision making purposes. Based on this point of view, the notion of earnings quality is defined differently by different users of financial statements.

Further, Dechow and Schrand (2004) explains that "analysts are likely to view earnings to be of high quality when the earnings numbers accurately reflect the company's current operating performance, are good indicators of future operating performance and are a good summary measure for assessing firm value. This is consistent with the objectives of financial analysts, which are to evaluate the performance of the company, assess the extent to which current earnings indicates future performance and determine whether the current stock price reflects intrinsic firm value. They are likely to have similar objectives. On the other hand, creditors and compensation committees may define high quality earnings as earnings that are easily convertible into cash flows and that reflect managers' real performance."

"Financial statement users may also define earnings quality in terms of the 'absence of earnings management'. This is because the intentional manipulation of earnings by managers, within the limits possible in accounting standards, may distort the usefulness of earnings to users. Earnings that are persistent and predictable may not be of high quality if it is a result of earnings management. Managers may tend to manage earnings for a number of reasons including those related to capital market motivations, compensation and bonus as well as debt or lending contracts, which will result in low quality of earnings. According to Schipper and Vincent (2003), debt agreements based on low and defective earnings will induce unintended wealth transfers; overstated earnings used as an indicator of managers' performance in compensation contracts will result in overcompensation to managers; and low quality of earnings will provide defective resource allocation signals to investors."

Dechow and Schrand (2004) state that when earnings conform to the spirit and the rules of generally accepted accounting principles, they are of high quality in the eyes of regulators. Earnings should be free from fraud and show a true and fair view of a company's financial performance. However, accounting standard setters are also concerned with the effectiveness of the standards that they have promulgated. By focusing on the usefulness of earnings numbers to financial statements users, standard setters can evaluate quality of

Earnings prepared under a particular set of accounting standards.

Other than the decision-usefulness context, earnings quality has also been explained in prior research using the economics-based definition of Hicksian income (e.g. Dempster, 2008; Hodge, 2003; Schipper and Vincent, 2003). Shipper and Vincent (2003, p. 98) define earnings quality as "the extent to which reported earnings faithfully represent Hicksian income, where representational faithfulness means correspondence or agreement between a measure or description and the phenomenon that it purports to represent". This construct measures the quality of earnings based on its correlation with 'true earnings', which does not depend on accounting recognition rules and the implementation of the accounting rules. 'True earnings' is a neutral and context-free benchmark, yet difficult to assess as Hicksian income is not observable.

However, since Hicksian earnings are not observable, the construct is not operational (Schipper and Vincent, 2003). Similar to the Hicksian income definition, Yee (2006) explains that earnings quality depends on two main elements, the 'fundamental' earnings and reported earnings. The former is a profitability figure that measures a firm's ability to make future dividend payments, while the latter is an imperfect signal or estimation of 'fundamental' earnings that a firm announces. According to Yee (2006), earnings quality is based on the ability of reported earnings to quickly and precisely reveal a firm's fundamental earnings. The more accurate and timely that reported earnings reflect shocks in the present value of expected future dividends, the higher the quality of earnings.

\section{Non-Financial Information}

In the past, annual reports only include financial measures. More recently, this shareholder value approach has been criticized of leading to a strategic short-term orientation. Consequently, the use of strategic performance measurement systems (SPMSs) is proposed to communicate non-financial measures to investors and stakeholders. Besides the distribution of critical information, the disclosure of non-financial measures should strengthen the 
employee's commitment to the long-term strategy. The current interest in multidimensional performance systems clearly necessitates systematic empirical investigation to ascertain their effectiveness and benefits. This study contributes in this regard by focusing on nonfinancial measures, a key component of multidimensional performance measurement systems. It also adds to our understanding of the process by such systems influence employee reactions and ultimately overall organizational performance.

\section{Corporate governance disclosure}

As a mechanism system to help managers in making decisions which suits the interest of various stakeholders, corporate governance is able to reduce the potential conflicts which might arise between management as the agent and shareholders as the principal (Lei, et al. 2013). In term of Corporate Governance Disclosure, both Islamic Banks predominantly comply with Principles of Governance set by AAOIFI, although there is a slight different between the two by $4 \%$ higher in Bahrain Islamic Bank for it reached 100\% compliance to AAOIFI Standard for Corporate Governance Disclosure.

"QIIB and BIB are committed to reach the higher International levels and apply the best international standards in prudent governance including standards regulated by Central Bank, Basel, etc. However, what makes difference is that QIIB has no information related to Corporate Governance (CG) in their annual report, yet they only disclose it separately in their Corporate Governance Report which also published annually. In contrast, BIB provides the Corporate Governance information both in a special section of Annual Report as well as in a full Corporate Governance Report. Therefore, as illustrates in Table 3, the only missing point on QIB's CG is the adequate transparency. Abdelsalam et al. (2016) Islamic banks should be encouraged to provide higher transparency as the realization of religious concept of Islamic accountability.

Table 3. AAOIFI Standard of Corporate Governance Disclosures

\begin{tabular}{|c|c|c|c|}
\hline No & Principles of Governance & QIIB & BIB \\
\hline & $\begin{array}{l}\text { Principle } 1 \text { : Effective Shariah compliance } \\
\text { structure }\end{array}$ & & \\
\hline 1 & $\begin{array}{l}\text { Appropriate governance structure for a } \\
\text { transparent shaniah compliance process }\end{array}$ & 1 & 1 \\
\hline 2 & $\begin{array}{l}\text { Transparent interaction between SSB and } \\
\text { management }\end{array}$ & 1 & 1 \\
\hline \multirow[t]{2}{*}{3} & SSB Report on compliance based & 1 & 1 \\
\hline & Principle 2 : Fair treatment of equity holders & & \\
\hline 4 & $\begin{array}{l}\text { Governance mechanism to protect equity } \\
\text { holders interest }\end{array}$ & 1 & 1 \\
\hline 5 & $\begin{array}{l}\text { Equity holders should have access to vital } \\
\text { corporate information }\end{array}$ & 1 & 1 \\
\hline \multirow[t]{2}{*}{6} & $\begin{array}{l}\text { BOD and management should accountable to } \\
\text { equity holders }\end{array}$ & 1 & 1 \\
\hline & $\begin{array}{l}\text { Principle } 3 \text { : Equitable treatment of fund } \\
\text { providers and other significant stakeholders }\end{array}$ & & \\
\hline 7 & $\begin{array}{l}\text { Governance mechanism to protect the risk of } \\
\text { fund provider and stakeholders }\end{array}$ & 1 & 1 \\
\hline \multirow[t]{2}{*}{8} & $\begin{array}{l}\text { Stakeholder should be provided with timely } \\
\text { info about major changes }\end{array}$ & 1 & 1 \\
\hline & $\begin{array}{l}\text { Principle } 4 \text { : Fit and proper conditions for } \\
\text { board and management }\end{array}$ & & \\
\hline 9 & $\begin{array}{l}\text { Selection of members of BOD, SSB, and } \\
\text { management should be transparent and based } \\
\text { on a predefined set of criteria }\end{array}$ & 1 & 1 \\
\hline & Principle 5 : Effective oversight & & \\
\hline 10 & $\begin{array}{l}\text { BOD has the responsibility to serve the } \\
\text { interest of IFI and Stakeholder }\end{array}$ & 1 & 1 \\
\hline 11 & BOD should set a clear strategic plan & 1 & 1 \\
\hline
\end{tabular}

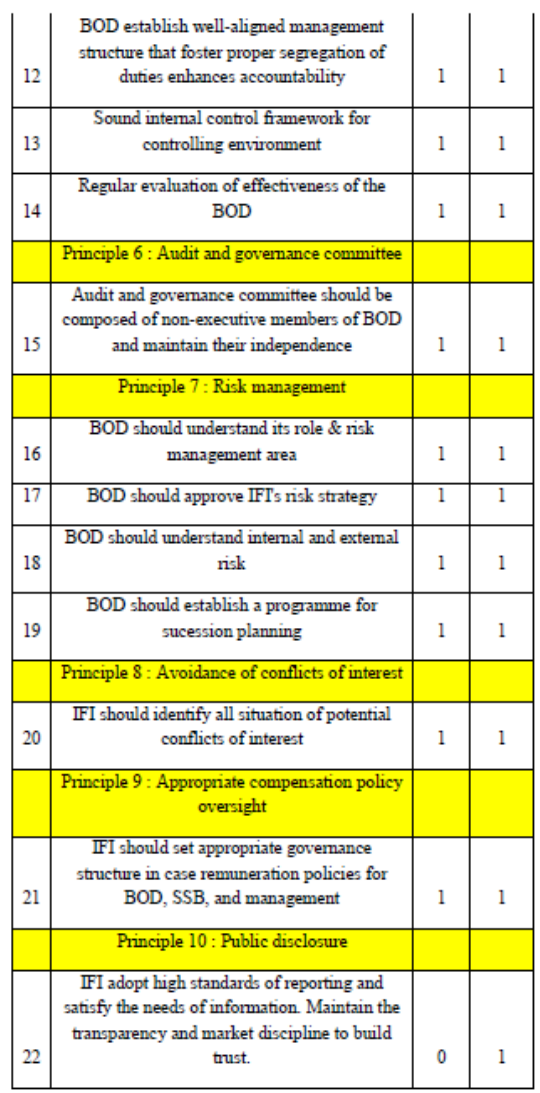

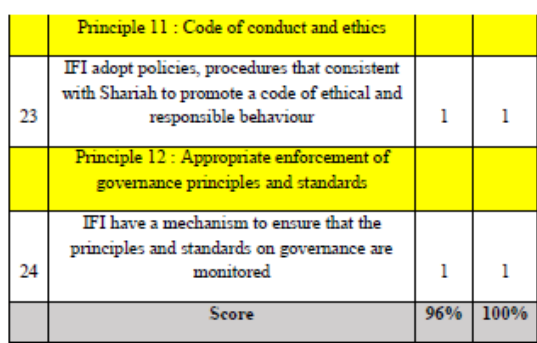

Source: Annual Report of BIB and QIIB

\section{a. Bank Ownership}

Both QIIB and BIB are public companies. As it can be clearly seen in Table 6 (Appendix 3), more than $60 \%$ of the BIB's ownership belongs to government institution which might cause agency problem type 2 between government and private corporation/individual (Uddin, 2016). Public enterprises are predicted to deal with the problem of inefficiency due to the tendency of serving political interest (Shleifer and Vishny, 1996). 
Regardless of that, in comparison to BIB, the shareholders of QIIB is less diverse since all of them are from its home country, Qatar. In addition to that, unlike QIIB, BIB is more transparent in disclosing the ownership shares of Directors and Shariah members.

Table 4. Shareholder Composition of BIB

\begin{tabular}{|c|c|c|c|}
\hline Shareholder & Type & Country & Holding \\
\hline Government of Bahrain & Government & Bahrain & $29.06 \%$ \\
\hline National Bank of Bahrain BSC & Government & Bahrain & $29.06 \%$ \\
\hline Islamic Development Bank & $\begin{array}{c}\text { Private } \\
\text { Corp }\end{array}$ & $\begin{array}{c}\text { Saudi } \\
\text { Arabia }\end{array}$ & $14.42 \%$ \\
\hline Government of Kuwait & Government & Qatar & $7.18 \%$ \\
\hline Public & - & - & $20.28 \%$ \\
\hline
\end{tabular}

Source: Eikon Thomson Reuters

Table 5. Shareholder Composition of QIIB

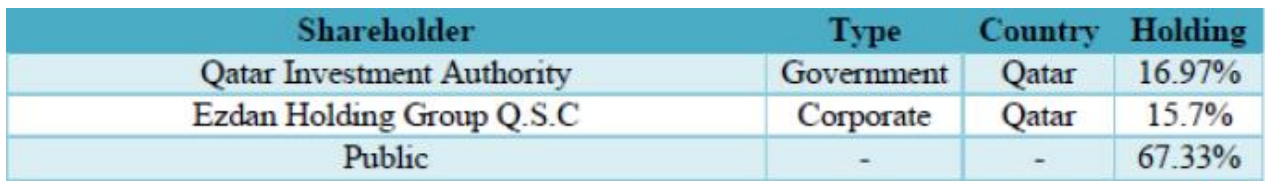

Source: Eikon Thomson Reuters

b. Board of Director and Committee

"In both QIIB and BIB organizational structure, they separated the position of Chairman and CEO which could lead to higher independency of Board (OECD, 1999). Unlike QIIB where all board members are male, BIB has one female board member. However, overall, both banks has good diversity in the composition of board members in term of the diverse experience and educational background (Table $7 \& 6$, Appendix 2). It is line with a study conducted by Hamzah and Zulkafli (2014) which found that Board diversity is crucial aspect in promoting good governance as well as enhancing the quality of the discussion. Meanwhile pertaining to cross-directorship, no robust regulation released by Central Bank of Qatar and Bahrain causes most of the board members of QIIB and BIB sit in several boards at the same time. QIIB did not disclose the Board Meeting Attendance although they were more active than BIB with 12 meetings held during a year. While BIB disclosed the full attendance of 7 Board Meetings held during a year with $80 \%$ level of attendance which is far above the minimum standard og $33 \%$ required by The Committee on the Financial Aspects of Corporate Governance. 1992) wh is 33\%. As regulated by QFMA, Banks must establish three committees namely audit, remuneration, and nomination committee. Both QIIB and BIB have fulfilled it”.

c. Shariah Supervisory Board (SSB)

"As QIIB and BIB did not provide information about how long the members of SSB have joined the board, we could not figure out the fulfilment of AAOIFI requirements in term of the replacement of their member every 5 years. Additionally, with regard to the limited disclosure provided by both Banks, we could only found the number of meetings held by BIB which are 4 times during a year with $95 \%$ level of attendance. Furthermore, the issue of cross-directorship and lack of diversity which often arise in many Islamic Banks are also observed in BIB since there is no relevant information on QIIB. In the SSB of BIB, 3 out of 4 members serve as a SSB members in more than 3 other banks. It clearly does not fulfil the requirement of CG code established by Capital Standards Qatar which only allows maximum 3 directorship. In addition to that, Belal et al. (2014) pointed out that cross-directorship might arise the concern on legitimacy and conflict of interest. While the lack of diversity on BIB's SSB members in term of gender (all members are male), nationality (all members are Bahraini), and education (3 out of 4 members holds Sharia-related degree) could lower the quality of information reported by board to stakeholders (García-Meca, García-Sánchez and Martínez-Ferrero, 2015).

In term of SSB-related disclosure, BIB disclosed more information than QIIB in their SSB report. Firstly we can observe it through the word count of the SSB report of BIB and QIIB which consist of 1171 and 111 words respectively. Secondly it can be observed from the content of the report. BIB disclosed relevant information regarding the profiles of SSB member, SSB meetings and attendance, earnings prohibited by Sharia, Sharia internal audit, and others. In contrary, QIIB only disclosed that they have done the shariacompliance review for both services and transactions." 


\section{Environmental Disclosure}

By referring to AAOIFI standard on environmental dimension (Table 9, Appendix 3), QIIB has higher score than BIB which shows better commitment toward environmental issue. Out of 4 indicators, Bahrain Islamic Bank only disclosed 1 indicator related to finding renewable energy for operational activities in the organization. While Qatar International Islamic Bank disclosed 3 out of 4 indicators, the only indicator they need to accomplish is providing incentives and initiatives to have a recycle process for renewable energy within organizations.

Table 6. AAOIFI Standard of Environmental Disclosures

\begin{tabular}{|c|c|c|c|}
\hline No & Environmental Policy & QIIB & BIB \\
\hline 1 & $\begin{array}{l}\text { Establishing organization wide guidelines on efficient } \\
\text { and minimal usage of non-renewable resources }\end{array}$ & 1 & 0 \\
\hline 2 & $\begin{array}{l}\text { Initiatives to educate employees to efficiently use } \\
\text { non-renewable resources and increase use of } \\
\text { renewable resources }\end{array}$ & 1 & 0 \\
\hline 3 & $\begin{array}{l}\text { Incentives and initiatives to find alternatives to non- } \\
\text { renewable sources of energy and materials for } \\
\text { operations (e.g e-mail bank statements instead of } \\
\text { paper bank statements) }\end{array}$ & 1 & 1 \\
\hline \multirow[t]{2}{*}{4} & $\begin{array}{l}\text { Incentives and initiatives to recycle renewable } \\
\text { sources of materials within the organization }\end{array}$ & 0 & 0 \\
\hline & Score & $75 \%$ & $25 \%$ \\
\hline
\end{tabular}

Source: Annual Report of BIB and QIIB

\section{Conclusion}

Based on results of data analysis discussed in the previous chapter, we could conclude that Qatar International Islamic Bank has outperformed Bahrain Islamic Bank for Environmental Disclosure, while for Corporate Governance Disclosure, Bahrain Islamic Bank has outperformed Qatar International Islamic Bank. It shows that the application of IFRS is still relevant to Islamic banking operation since there are several similarities between IFRS and AAOIFI. However, as the component of Corporate Governance disclosure is broader than that of Environmental Disclosure, it can be said that Bahrain Islamic Bank has a better transparency than Qatar International Islamic Bank due to the different characteristic of culture dimension in each country. For Bahrain having low level of power distance, individualism, and uncertainty avoidance, it expresses greater preference for transparency than Qatar with high power distance (Jain, 2018). This low level of transparency eventually could cause the low score obtained for earnings quality (Tucker, 2015). Further research is suggested to have another indicator of financial performance for Islamic banks and to cover more Islamic banks worldwide with the data from recent years.

\section{References}

AAOIFI, (2015). Accounting, Auditing and Governance Standards. Manama: Dar AlMaiman.

Abdelsalam, O., Dimitropoulos, P., Elnahass, M. \& Leventis, S. (2016). Earnings Management Behaviors under Different Monitoring Mechanisms: The Case of Islamic and Conventional Banks. Journal of Economic Behavior \& Organization (special issue on Islamic Finance).

Belal, A., Abdelsalam, O. and Nizamee, S. (2014). Ethical Reporting in Islami Bank Bangladesh Limited (19832010). Journal of Business Ethics, 129(4), pp.769-784.

Capital Standards, (2010). CSR's Corporate Governance Code: Principles \& Recommended Best Practices for Public Companies. Qatar.

Cho, C., Roberts, R. and Patten, D. (2010). The Language of US Corporate Environmental Disclosure.Accounting, Organizations and Society, 35(4), pp.431-443. 
DICTION. (2013). Digitext, Inc.

Eikon. (2012). Thomson Reuters Database.

Ferrouhi, E. (2014). Moroccan Banks Analysis Using CAMEL Model. International Journal of Economics and Financial Issues, 4(3), pp.622-627.

García-Meca, E., García-Sánchez, I. and Martínez-Ferrero, J. (2015). Board Diversity and Its Effects on Bank Performance: An International Analysis. Journal of Banking \& Finance, 53, pp.202-214.

Gasbarro, D., Sadguna, I. and Zumwalt, J. (2002). The Changing Relationship Between CAMEL Ratings and Bank Soundness during the Indonesian Banking Crisis. Review of Quantitative Finance and Accounting, 19, pp.247-260.

Hamzah, A. and Zulkafli, A. (2014). Board Diversity and Corporate Expropriation. Procedia - Social and Behavioral Sciences, 164, pp.562-568.

Lei, Q., Lin, B. and Wei, M. (2013). Types of Agency Cost, Corporate Governance and Liquidity.Journal of Accounting and Public Policy, 32(3), pp.147-172.

Maali, B., Casson, P. and Napier, C. (2006). Social reporting by Islamic Banks. Abacus, 42(2), pp.266-289.

Mallin, C. (2013). Corporate Governance. 4th ed. Oxford: Oxford University Press.

Merchant, I. P. (2012). Performance analysis of banks using CAMEL approach, An Empirical

study of Islamic Banks Versus Conventional Banks of GCC.

Merkl-Davies, D. and Brennan, N. (2007). Discretionary Disclosure Strategies in Corporate Narratives: Incremental Information or Impression Management?. Journal of Accounting Literature, 26, pp.116-196.

Qatar Financial Market Authority, (2009). Corporate Governance Code For Companies Listed in Markets Regulated by The Qatar Financial Markets Authority.

Sarker, A. (2006). CAMELS Rating System in the Context of Islamic Banking: A Proposed ' $S$ ' for Shariah Framework. Journal of Islamic Economics, Banking and Finance, 2(2).

Shleifer, A. and Vishny, R. (1997). A Survey of Corporate Governance. The Journal of Finance, 2(2), pp.737-783.

The Committee on the Financial Aspects of Corporate Governance, (1992). Financial Aspects of Corporate Governance. London: Gee and Co. Ltd.

Uddin, M. (2016). Effect of Government Share Ownership on Corporate Risk Taking: Case of the United Arab Emirates. Research in International Business and Finance, 36, pp.322-339. 